\section{Rapid PCR Construction of a Gene Containing Lym-1 Antibody Variable Regions}

\author{
Xu-Bao Shi, ${ }^{1}$ \\ Paul H. Gumerlock, \\ Arthur A. Wellman, \\ Claude F. Meares,' \\ Gerald L. DeNardo, 1 \\ Frederick J. Meyers, \\ and Sally J. DeNardo'
}

\footnotetext{
${ }^{1}$ Department of Internal Medicine, University of California, Davis, Medical Center, Sacramento, California 95817; ${ }^{2}$ Department of Chemistry, University of California, Davis, California 95616
}

Clinical applications of monoclonal antibodies (mAbs) to tumor-associated antigens provide potential for targeted cancer therapy. Radiolabeled mAb Lym-1 has been used successfully to treat $>50$ patients with B-cell lymphoma. ${ }^{(1-3)}$ The uptake of Lym-1 in lymphomas is rapid and efficient compared with solid tumors. However, the amount of the radioactive dose injected on these large molecules reaching each gram of tumor is usually $<0.1 \%$. When Lym- 1 is labeled with radiometal chelates to enhance its tumoricidal effects, there is undesirable accumulation and slow clearance of radioactivity in the liver. Evidence suggests that this is related to receptors for components of the mAb Fc region. ${ }^{(4,5)}$ Recent studies ${ }^{(6,7)}$ have demonstrated that two recombinant radio-directed single-chain antigen-binding (SCA) proteins derived from monoclonal antibodies have in vivo tumor-targeting capacity. Although the percent injected dose per gram of tumor is low, the therapeutic index (tumor to normal organ radiation dose) is several times that of the intact $m A b, F\left(a b^{\prime}\right)_{2}$, or $F^{\prime} b^{\prime}$ fragments. ${ }^{(7)}$ This improvement in biokinetics properties of the radiolabeled SCA protein make it a promising agent for alternative therapeutic strategies. Furthermore, SCA proteins facilitate development of single or bispecific radioimmunoconjugates, humanized antibodies, or new versions of tumor-reactive molecules for immunotherapy. This may be particularly rewarding for a mAb such as Lym-1 that has already been demonstrated to be successful in clinical radioimmunoconjugate cancer therapy.

Gene engineering techniques have been used to produce the SCA protein, which consists of the heavy-chain variable region $\left(\mathrm{V}_{\mathrm{H}}\right)$ and the light-chain variable region $\left(\mathrm{V}_{\mathrm{L}}\right)$ of an antibody synthesized as a single polypeptide. ${ }^{(8)}$ In this engineered protein, the carboxyl terminus of one variable region is linked by a linker peptide to the amino terminus of the other. Some are $\mathrm{V}_{\mathrm{H}}-\mathrm{V}_{\mathrm{L}}$ and some are $\mathrm{V}_{\mathrm{L}}-\mathrm{V}_{\mathrm{H}}$.

Obtaining the $\mathrm{V}_{\mathrm{H}}$ and $\mathrm{V}_{\mathrm{L}}$ coding regions is the first step for production of an SCA protein. Several strategies to generate these coding regions are available. Variable-region sequences can be assembled using overlapping synthetic oligonucleotides designed from the protein sequence, and then transferred into vectors for expression. ${ }^{(9,10)}$ Alternatively,
cDNA libraries coding for the heavy and light chains can be constructed, and restriction sites can be introduced in the cDNAs by site-directed mutagenesis at the $5^{\prime}$ and $3^{\prime}$ ends of both variable regions. ${ }^{(11)}$ These strategies require detailed knowledge of the antibody gene sequence. However, this information is not available for many antibodies and is not required for the strategy described here.

PCR has been used to amplify the sequences encoding the variable domains of antibodies. ${ }^{(12)}$ The technique has also been used by some investigators to assemble different genes for expression. ${ }^{(13,14)}$ Generally, two target DNA fragments are separately amplified by PCR with primers that create products that share a common sequence at one end of each fragment. These products are then mixed and denatured, and upon annealing, the positive strand of one fragment can hybridize with the negative strand of the other fragment (and vice versa) at the common sequence position. These partially double-stranded fragments become the templates for further PCR. Fusion of four PCR-generated DNA fragments requiring three separate reactions has been described in one report. ${ }^{(13)}$ An alternative method has been described wherein all the overlapping oligonucleotides comprising the entire gene were synthesized. ${ }^{(15)}$ These oligonucleotides were phosphorylated at the $5^{\prime}$ ends and ligated together to generate a target DNA template for PCR amplification. In this method, the requirement to synthesize the entire gene sequence and to phosphorylate the oligonucleotides is expensive and cumbersome.

In a different approach, Dillon and Rosen ${ }^{(16)}$ were able to synthesize the small HIV-2 Rev protein gene of $303 \mathrm{bp}$ by PCR using four overlapping synthetic oligonucleotides. We built on this concept and report here the generation of the 954-bp Lym-1 SCA protein gene. Our approach was to use PCR to amplify the $\mathrm{V}_{\mathrm{H}}$ and $\mathrm{V}_{\mathrm{L}}$ coding regions of Lym-1 heavy- and light-chain cDNAs separately. These products were then included in a PCR reaction with 9 synthetic oligonucleotides. Six of these oligonucleotides created a 5 ' restriction site for cloning, a hybrid $\lambda$ phage promoter $\left(o_{\mathrm{L}} /\right.$ $p_{\mathrm{R}}$ ), a Shine/Dalgarno (SD) sequence for ribosomal translation, and a signal peptide sequence (ompA). Two oligonucleotides created a 14-amino-acid peptide 
linker between the $V_{H}$ and $V_{L}$ fragments, and the ninth oligonucleotide added two translational stop codons and a $3^{\prime}$ restriction site. This gene fusion by PCR created a complete SCA protein gene (954 bp) for expression in a bacterial system. Also, discussed here are strategies for $V_{H}$ and $V_{L}$ amplification and singlestranded DNA sequencing.

\section{MATERIALS AND METHODS}

\section{Primers and Probes for $V_{H}$ and $V_{L}$ Amplification}

Table 1 lists the DNA oligonucleotides that were used to amplify and probe the Lym- $1 \mathrm{mAb} \mathrm{V}_{\mathrm{H}}$ and $\mathrm{V}_{\mathrm{L}}$ gene transcripts that had been reverse-transcribed into cDNA. Primers HS-1 and $\kappa-\mathrm{N}^{\prime}$ were graciously provided by Dr. D. L. Robbins (Department of Rheumatology, University of California Davis Medical Center, Sacramento) and have been described previously. ${ }^{(17)}$ These oligonucleotides were designed to amplify a wide range of human heavy- and light-chain genes and are targeted to the conserved leader se- quence (HS-1) and the $\kappa$ constant region $\left(\kappa-\mathrm{N}^{\prime}\right)$ within the coding regions of the genes. HS-1 is a mixture of eight oligonucleotides due to variation at three positions (see Table 1). These primers were not further purified upon receipt and were used to amplify the cDNA from a mouse mAb. Oligonucleotides PO3, G2A, 1G, PO2, and 1A were synthesized in-house and purified by reverse-phase HPLC. These were the primers used to obtain the initial Lym-1 $\mathrm{V}_{\mathrm{H}}$ and $\mathrm{V}_{\mathrm{L}}$ sequences. ${ }^{(18)}$ The oligonucleotides $\gamma$-15 and $\kappa-17$ were purchased from a commercial source (Pharmacia LKB Biotechnology, Piscataway, NJ), reconstituted according to the supplier's instruction, and not purified further.

\section{Amplification of $m A b V_{H}$ and $V_{L}$ Coding Regions}

RNA/PCR amplification was performed using a modification of the method described in our previous paper. ${ }^{(19)}$ In brief, whole RNA was extracted from the Lym-1 hybridoma cell line using an acid guanidinium thiocyanate-phenol-chlo- roform extraction method. ${ }^{(20,21)}$ Hybridoma cells $\left(1 \times 10^{7}\right)$ were harvested and dissolved in $3 \mathrm{ml}$ of $5 \mathrm{~m}$ guanidinium thiocyanate. The lysate was centrifuged for $18 \mathrm{hr}$ at $35,000 \mathrm{rpm}$ through a cesium chloride density gradient. The RNA pellet was resuspended and subjected to two phenol/chloroform extractions. After the second extraction, the RNA in the aqueous phase was precipitated by adding two volumes of cold $100 \%$ ethanol. The RNA pellet was obtained by microcentrifugation at $4^{\circ} \mathrm{C}$ for $15 \mathrm{~min}$. CDNA was generated by reverse transcription of $\sim 1$ $\mu \mathrm{g}$ of RNA in a $20-\mu \mathrm{l}$ reaction mixture using a random hexadeoxynucleotide primer. ${ }^{(19)}$

Using the cDNA reaction mixture, the target DNA was amplified by Taq DNA polymerase (Perkin-Elmer Cetus, Norwalk, CT). The reaction was set up by mixing $10 \mu \mathrm{l}$ of $10 \times$ PCR buffer [final buffer composition was $50 \mathrm{~mm} \mathrm{KCl}, 10$ $\mathrm{mM}$ Tris- $\mathrm{HCl}\left(\mathrm{pH} \mathrm{8.3)}, 2.5 \mathrm{~mm} \mathrm{MgCl}_{2}\right.$, and $0.01 \%$ gelatin], $100 \mu \mathrm{M}$ each of dNTPs, 20 pmoles of each primer, 2 units of Taq DNA polymerase, and $2 \mu \mathrm{l}$ of cDNA in a volume of $100 \mu \mathrm{l}$. The amplification was performed in an automated

TABLE 1 The Primers and Probes Used for Amplification and Probing of Lym-1 $\mathrm{V}_{\mathrm{H}}$ and $\mathrm{V}_{\mathrm{L}} \mathrm{cDNAs}$

$$
\begin{aligned}
& \text { Primers for } \mathrm{V}_{\mathrm{H}} \text { amplification and binding positions: } \\
& \text { upstream: HS-1. GGGAATTCATGGACTGGACCTGGAGG(AG)TC(CT)TCT(GT)C (-55 - -21) } \\
& \text { downstream: PO3. ACACCACTGGACAGGGATCCAGAG } \\
& (537-560) \\
& \text { G2A. GTTGTATCTCCACACAC } \\
& (451-467) \\
& \text { Probes for } \mathrm{V}_{\mathrm{H}}: \boldsymbol{\gamma} \text {-15. GGCCAGTGGatagaC } \\
& \text { 1G. GGCTCTTGGAGTTGTCC } \\
& (433 \text { - 447) } \\
& (270 \text { - 286) } \\
& \text { upstream: PO2. CTCAGGTCCTGGGGTTGCTGCTGC } \\
& \text { downstream: } \mathbf{k}-\mathbf{N} \text { '. CCAAGCTTCATCAGATGGCGGGAAGAT } \\
& (396-442) \\
& \text { Probes for } V_{L}: \text { k-17. TGgATGgTgGgaAgatg } \\
& (395-410) \\
& \text { 1A. AGGAGCTGAGGAGATTT }
\end{aligned}
$$

All sequences are listed $5^{\prime} \rightarrow 3^{\prime}$. The numbers in parentheses represent the primer-binding-positions as numbered in Fig. 4. 


\section{Technical TipsIIIII}

DNA thermal cycler (Perkin-Elmer Cetus) for 35 cycles, with each cycle consisting of $30 \mathrm{sec}$ at $95^{\circ} \mathrm{C}, 30 \mathrm{sec}$ at $65^{\circ} \mathrm{C}$, and $30 \mathrm{sec}$ at $72^{\circ} \mathrm{C}$. The amplified products were electrophoresed in a $2 \%$ NuSieve/1\% agarose gel.

\section{Southern Blotting}

The amplified mAb $V_{H}$ and $V_{L}$ cDNAs were confirmed by Southern blotting. ${ }^{\text {(22) }}$ The PCR products were electrophoresed in a $1.5 \%$ agarose gel for $1.5 \mathrm{hr}$ at $110 \mathrm{~V}$. The DNA in the gel was transferred to a Biotrans nylon membrane (ICN Biomedicals, Irvine, $\mathrm{CA}$ ) in $0.4 \mathrm{~N} \mathrm{NaOH}$. The probes, labeled with biotin-dUTP, were hybridized with the transferred $\mathrm{V}_{\mathrm{H}}$ and
$V_{L}$ DNAs on the membrane. The hybridized probe was detected by an enzymatic chemiluminescence method. ${ }^{(23)}$

\section{Production of Single-stranded DNA}

The amplified DNA was purified using a low melting point (LMP) agarose gel. ${ }^{(21)}$ First, the PCR product was electrophoresed in a $1.5 \%$ agarose gel. After separation of the target DNA band from other bands, a well was made in the same lane by cutting out a piece of gel in the positive direction close to the target DNA band. The well was filled with $1 \%$ LMP agarose syrup that was gelled at $4^{\circ} \mathrm{C}$. The gel was subjected to a second run for $20 \mathrm{~min}$ to move the target DNA band into the LMP agarose gel. The piece of LMP agarose gel containing the DNA band was cut out and stored at $4^{\circ} \mathrm{C}$ until used.

The purified double-stranded DNA was used to generate single-stranded DNA by an asymmetric PCR amplification protocol. ${ }^{(24)}$ Two to five microliters of melted LMP agarose gel containing the purified DNA and $2 \mu$ l of primer solution (10 pmoles/ $\mu$ l of upstream or downstream primer) was added to $100 \mu \mathrm{l}$ of PCR reaction buffer containing 2 units of Taq DNA polymerase, and the reaction was run for 40 cycles as described above. The asymmetric amplified product $(10 \mu \mathrm{l})$ was electrophoresed in a $1.5 \%$ agarose gel. The DNA was visualized after

TABLE 2 The Synthetic Oligonucleotides for PCR Fusion

1. EOP-L1

GAATTTATTTTTTGCAGGGGGGCATTGTTTGGTAGGTGAGAGAGATCCCGGAATTCCGG

2. EOP

CCGGAATTCCGGGATCTCTCTC

3. EOP-L2

CATACAACCTCCTTAGTACATGCAACCATTATCACCGCCAGAGGTAAAATAGTCAACACCGCCAGAGATAATTTATC

4. EOP-U

UCCCCTGCAAAAAATAAATTCATATAAAAAACATACAGATAACCATCTGCGGTGATAAATTATCTCTGGCGGTG

5. ompA-L

TGGAGACTGAGTCATCTGGATGTCGGCCTGCGCTACGGTAGCGAAACCAGCCAGTGCCACTG

6. ompA-U

TGTACTAAGGAGGTTGTATGGATGAAAAAGACAGCTATCGCGATTGCAGTGGCACTGGCTGG

7. Link-L

GCCAGGTCCTGACTCCTTCAGCTGCACCTGACCTTTACCTTCAGAAGATTTACCAGAACC

8. Link-U

TCGGCTCGGGGACAAAGTTGGAAATAAAAGGTTCTACCTCTGGTTCTGGTAAATCTTCTG

9. $\mathrm{PO} 3$

ACACCACTGGACAGGGATCCAGAG

10. BSH

CGCGGATCCGCGTTATTATGCAGAGACAGTGACCAGAGTCCC

All sequences are listed $5^{\prime} \rightarrow 3^{\prime}$. 
staining with ethidium bromide and exposure to UV light. The single-stranded DNA was purified by Centricon-100 (Amicon, Beverly, MA) centrifugation to remove the extra dNTPs and primers. In addition, the double-stranded PCR products were cloned into the TA-cloning vector (Invitrogen, San Diego, CA) for sequencing according to the supplier's instructions.

\section{DNA Sequencing}

The purified single-stranded DNA was suitable for sequencing using the Sanger chain-termination method, ${ }^{(25)}$ with S-35-dATP (DuPont NEN Research Products, Boston, MA) and T7 DNA polymerase (Sequenase 2.0, U.S. Biochemical, Cleveland, $\mathrm{OH}$ ). Approximately 100 ng of the single-stranded DNA produced by PCR was incubated with 2.5 pmoles of sequencing primer at $94^{\circ} \mathrm{C}$ for $4 \mathrm{~min}$, and the vial containing the mixture was placed in a dry ice-ethanol bath until used. The mixture was brought to room temperature and the cDNA sequenced according to the manufacturer's protocol. The synthesized DNA was electrophoresed in a denaturing $6 \%$ polyacrylamide gel. Autoradiographic exposure on Kodak XAR X-ray film varied from 1 to 5 days depending on the radioactivity in the gel.

\section{Oligonucleotides for Gene Construction by PCR}

Primer PO3 and 9 oligonucleotides (22$77 \mathrm{bp}$ ) coding the hybrid $\lambda$ phage promoter $o_{\mathrm{L}} / p_{\mathrm{R}}$, the SD sequence, the $o m p A$ signal sequence, a 14-amino-acid linker, EcoRI and BamHI cloning sites, and a pair of translational stop codons were synthesized in the University of California Davis Protein Structure Laboratory (Table 2). The deprotected singlestranded DNA products were supplied by the manufacturer in two different forms: trityl-on and trityl-off. All of the oligonucleotides were purified before use. The trityl-on products were purified using Poly-Pak cartridges (Glen Research Corporation, Sterling, VA) according to the supplier's instructions. The trityl-off oligonucleotides were purified by desalting on a G-50 resin (Bio-Rad Laboratories, Hercules, CA) column. These oligonucleotides were designed so that the last 16-21 nucleotides of each were complementary to the first part of the next strand. The oligonucleotides in close proximity to the PCR-amplified $\mathrm{V}_{\mathrm{H}}$ and $\mathrm{V}_{\mathrm{L}}$ coding regions shared 24- and 30-nucleotide overlaps with these regions, respectively.

\section{Gene Fusion by PCR}

The complete gene was constructed from the double-stranded $\mathrm{V}_{\mathrm{H}}$ and $\mathrm{V}_{\mathrm{L}}$ coding regions and a series of nine overlapping single-stranded DNA fragments by PCR, using an extension of the method of Dillon and Rosen. ${ }^{(16)}$ The principle of the method is illustrated in Figure 1. When mixed together, these nucleic acid fragments could be assembled into a hybrid representing the complete SCA gene, as shown in Figure 1. The fused gene was constructed by a two-step PCR: fusion and amplification. Standard conditions using Taq DNA polymerase yielded products that contained sequence errors (data not shown). Therefore, we used Vent $_{\mathrm{R}}$ DNA polymerase (New England Biolabs, Beverly, MA). The fusion step was set up according to the supplier's protocol, by mixing $5 \mu$ of $10 \times$ Vent $_{\mathrm{R}}$ buffer [final buffer composition was $10 \mathrm{mM} \mathrm{KCl}, 20 \mathrm{~mm}$ Tris$\mathrm{HCl}\left(\mathrm{pH}\right.$ 8.8), $4 \mathrm{~mm} \mathrm{MgSO}_{4}, 10 \mathrm{~mm}$ $\left(\mathrm{NH}_{4}\right)_{2} \mathrm{SO}_{4}$, and $0.1 \%$ Triton X-100], 100
A
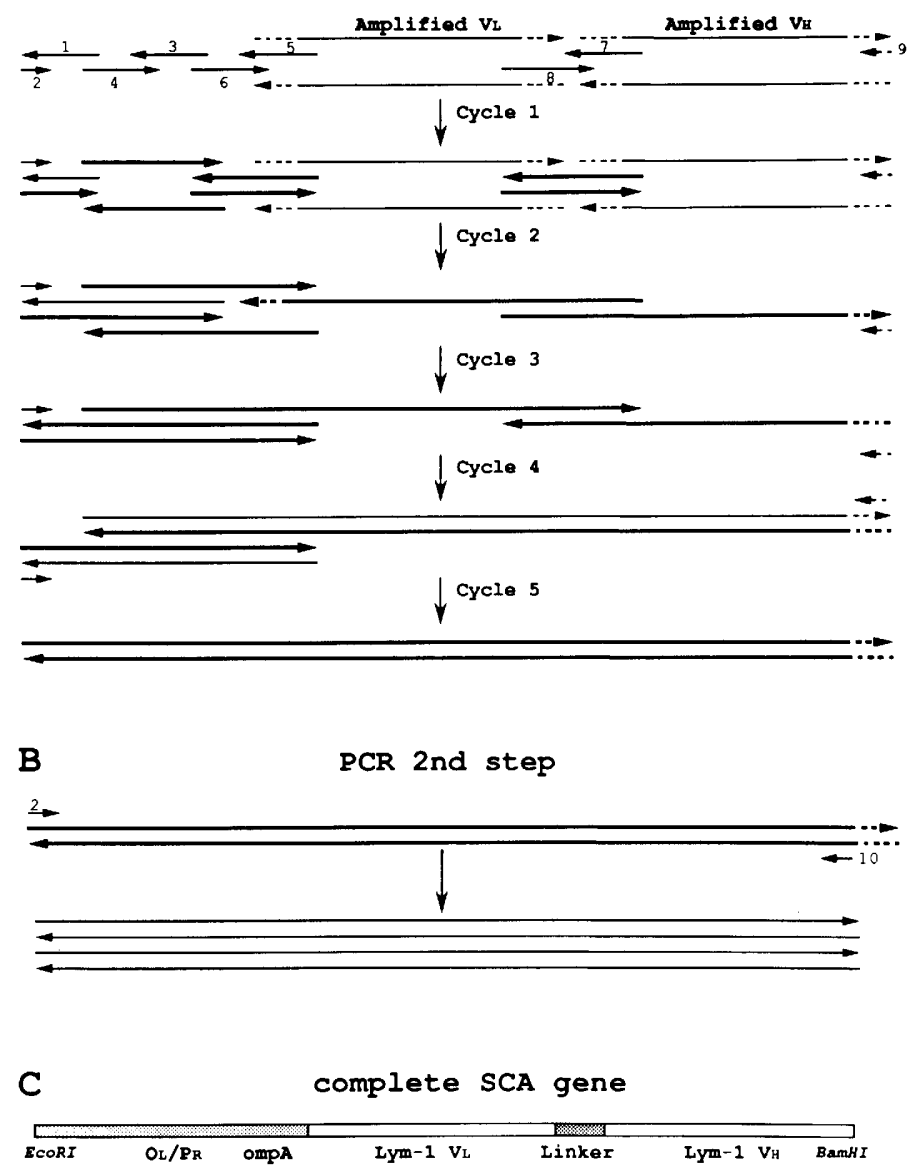

FIGURE 1 Strategy used to generate the Lym-1 SCA protein gene by a two-step PCR. $(A)$ The PCR first step. The eight short lines (1-8) represent the synthetic oligonucleotides listed in Table 2. Number 9 (PO3) is a primer to the constant region of heavy chain and is used to generate the Lym-1 SCA gene with some of the antibody constant region. The PCR-produced $V_{H}$ and $V_{L}$ coding regions are shown by four long lines; the broken lines represent the signal sequences at $5^{\prime}$ ends and the constant regions at $3^{\prime}$ ends. The arrows indicate the $5^{\prime} \rightarrow 3^{\prime}$ direction. The bold lines represent the products used as templates for the next cycle. The complete Lym-1 SCA protein gene containing a portion of the constant region of the heavy chain is assembled by the initial five cycles. The product is doubled by cycle 6 (not drawn). (B) The PCR second step. The DNA fused in step 1 is used as a template, and the SCA protein gene was amplified with primers EOP and BSH (10) listed in Table 2. (C) Diagram of the Lym-1 SCA protein gene. 


\section{Technical TipsllIII}
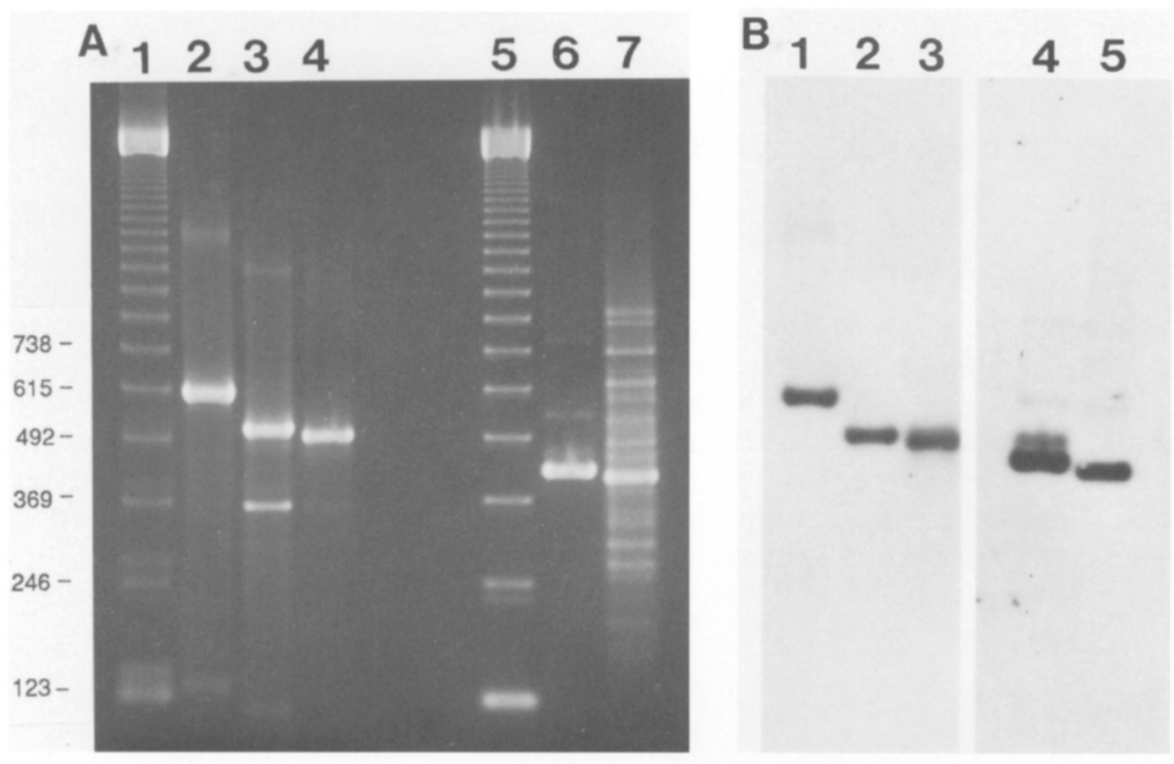

FICURE 2 Gel electrophoretic analysis of PCR products of Lym- $1 \mathrm{~V}_{\mathrm{H}}$ and $\mathrm{V}_{\mathrm{L}}$ cDNAs. $(A)$ Ethidium bromide-stained $2 \%$ NuSieve $/ 1 \%$ agarose gel with PCR-amplified products of Lym-1 $V_{H}$ and $V_{L}$ coding regions. (Lanes 1,5) 123-bp DNA marker ladder (bp at left); (lanes 2-4) $\mathrm{V}_{\mathrm{H}}$ coding region amplified using HS-1/PO3, HS-1/G2A, and HS-1/ $\gamma$-15, respectively; (lanes 6,7) $\mathrm{V}_{\mathrm{L}}$ coding region amplified using PO2/ $/ \mathrm{N}^{\prime}$ and $\mathrm{PO} 2 / \mathrm{\kappa}-17$, respectively. (B) Southern blot analysis of the amplified Lym-1 $V_{H}$ and $V_{L}$ cDNA products using probe $1 \mathrm{G}$ or $1 \mathrm{~A}$. (Lanes 1-3) Amplified $\mathrm{V}_{\mathrm{H}}$ coding region probed using 1G; (lanes 4,5 ) amplified $\mathrm{V}_{\mathrm{L}}$ coding region probed using $1 \mathrm{~A}$.

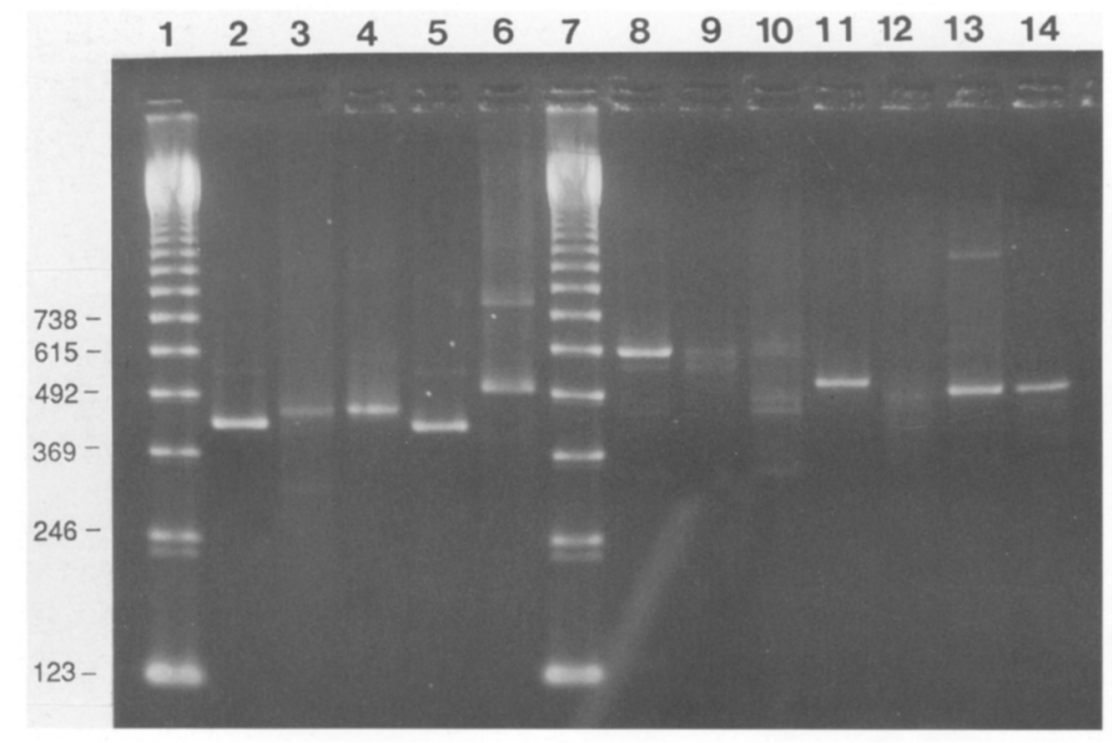

FIGURE 3 Gel electrophoretic analysis of double- and single-stranded DNA generated by PCR of Lym-1 $\mathrm{V}_{\mathrm{H}}$ and $\mathrm{V}_{\mathrm{L}}$ cDNAs. (Lanes 1,7) 123-bp DNA marker ladder (bp at left). (Lane 2) Products amplified with $\mathrm{V}_{\mathrm{L}}$ primers $\mathrm{PO} 2$ and $\kappa-\mathrm{N}^{\prime}(422 \mathrm{bp}$ ); (lanes 3,4 ) products generated by asymmetric PCR of lane 2 double-stranded products by primers PO2 and $\kappa-\mathrm{N}^{\prime}$, respectively; (lane 5) products of $\mathrm{V}_{\mathrm{L}}$ primers PO2 and $\kappa-17(410 \mathrm{bp}$ ); (lane 6) products generated by asymmetric PCR of lane 5 products by primers $\kappa-17$; (lane 8 ) products of $\mathrm{V}_{\mathrm{H}}$ primers HS-1 and PO3 (615 bp); (lanes 9,10) products generated by asymmetric PCR of lane 8 products by primers HS- 1 and PO3, respectively; (lane 11) products of $\mathrm{V}_{\mathrm{H}}$ primers HS-1 and G2A (522 bp); (lane 12) products generated by asymmetric PCR of lane 11 products by primer G2A; (lane 13) products of $\mathrm{V}_{\mathrm{H}}$ primers $\mathrm{HS}-1$ and $\gamma-15(502 \mathrm{bp}$ ); (lanes 14$)$ products generated by asymmetric PCR of lane 13 products by primer $\gamma-15$. $\mu \mathrm{g} / \mathrm{ml}$ of BSA, $200 \mu \mathrm{M}$ each of dNTPs, 20 pmoles each of the oligonucleotides, 2 $\mu \mathrm{l}$ each of the amplified $\mathrm{V}_{\mathrm{H}}$ and $\mathrm{V}_{\mathrm{L}}$ coding regions prepared above, and 1 unit of Vent $_{\mathrm{R}}$ DNA polymerase, in a final volume of $50 \mu \mathrm{l}$. The mixture was subjected to 6 thermal cycles, each consisting of 30 $\mathrm{sec}$ at $95^{\circ} \mathrm{C}, 30 \mathrm{sec}$ at $65^{\circ} \mathrm{C}$, and $60 \mathrm{sec}$ at $72^{\circ} \mathrm{C}$. Primer PO3 was used in this step to generate a complete Lym-1 SCA gene that carried part of the constant region of the heavy chain on the $3^{\prime}$ end as a template, which could be amplified effectively by primer EOP and BSH in the heminested PCR second step. The PCR second step was amplification that was set up by mixing $10 \mu$ l of the PCR-fused DNA fragment mixture from step 1 with the two primers EOP and BSH (Table 2) and run for 30 cycles.

\section{RESULTS}

\section{Amplification and Detection of $\mathbf{m A b}$ Variable Region Genes}

As shown in Figure 2A, cDNAs generated by reverse transcription of RNA extracted from a hybridoma cell line were successfully amplified using the primers listed in Table 1. For the heavy chain of Lym-1, primers HS-1 and PO3 amplified a DNA fragment of $615 \mathrm{bp}$; primers HS-1 and G2A amplified a DNA fragment of 522 bp. For the light chain of Lym-1, a DNA fragment with 422 bp was generated with primers PO2 and $\kappa-\mathrm{N}^{\prime}$. The amplified variable regions were confirmed by Southern blotting (Fig. 2B).

\section{Sequencing}

The single-stranded DNA for nucleotide sequencing was generated by an asymmetric PCR amplification. Figure 3 illustrates the results of these asymmetric amplifications. In lanes 1 and 7 are the 123-bp DNA marker ladders. Doublestranded DNA products, as templates for asymmetric amplification, are shown from PCR of Lym-1 cDNA with these primers: $\mathrm{V}_{\mathrm{L}}$ primers $\mathrm{PO} 2$ and $\kappa-\mathrm{N}^{\prime}(422$ $\mathrm{bp}) ; \mathrm{V}_{\mathrm{L}}$ primers $\mathrm{PO} 2$ and $\kappa-17$ (410 bp); $\mathrm{V}_{\mathrm{H}}$ primers HS-1 and PO3 (615 bp); $\mathrm{V}_{\mathrm{H}}$ primers HS-1 and G2A (522 bp); $\mathrm{V}_{\mathrm{H}}$ primers HS- 1 and $\gamma-15$ (502 bp). Singlestranded DNA products of asymmetric PCR of the double-stranded templates listed above are these: template amplified with $V_{L}$ primers $\mathrm{PO} 2$ and $\kappa-\mathrm{N}^{\prime}$, respectively; template amplified with $V_{L}$ 
Lym-1 Heavy Chain Variable Region DNA Sequence

5. GGGAA TTCATGGACT GGACCTGGAG GGTCCTCTTC TCATAGAGCC TCCATCAGAG

ATG GCT GTC CTG GGG CTG CTT CTC TGC CTG GTG ACT TTC CCA AGC TGT GTC CTG TCC CAG 60 Met Ala Val Leu Gly Leu Leu Leu Cys Leu Val Thr phe Pro Ser Cys Val Leu Ser Gln

GTG CAG CTG AAG GAG TCA GGA CCT GGC CTG GTG GCG CCC TCA CAG AGC CTG TCC ATC ACA 120 Val Gin Leu Lys Glu Ser Gly Pro Gly Leu Val Ala pro Ser Gln Ser Leu Ser Ile Thr

TGC ACC ATC TCA GGG TTC TCA TTA ACC AGC TAT GGT GTA CAC TGG GTT CGC CAG CCT CCA 180 Cys Thr Ile Ser Gly phe Ser Leu Thr Ser Tyr Gly Val His Trp Val Arg Gln pro pro

GGA AAG GGT CTG GAG TGG CTG GTA GTG ATA TGG AGT GAT GGA AGC ACA ACC TAT AAT TCA 240 Gly Lys Gly Leu Glu Trp Leu Val Val Ile Trp Ser Asp Gly Ser Thr Thr Tyr Asn Ser

GGT CTC AAA TCC AGA CTG AGC ATC AGC AAG GAC AAC TCC AAG AGC CAA GTT TTC TTA AAA 300 Ala Leu Lys Ser Arg Leu Ser Ile Ser Lys Asp Asn Ser Lys Ser Gln Val Phe Leu hys

ATG AAC AGT CTC CAA ACT GAT GAC ACA GCC ATA TAC TAC TGT GCC AGT CAC TAC GGT AGT 360 Met Asn Ser Leu Gln Thr Asp Asp Thr Ala Ile Tyr Tyr Cys Ala Ser His Tyr Gly SER

ACC CTT GCC TUT GCT TCC TGG GGC CAC GGG ACT CTG GTC ACT GTC TCT GCA GCC AAA ACA 420 Thr Leu Ala Phe Ala Ser Trp Gly His Gly Thr Leu Val Thr Val Ser Ala

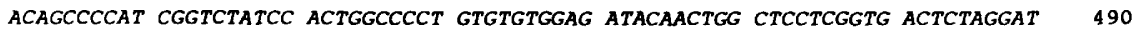
GCCTGGTCAA GGGTTATTTC CCTGAGCCAG TGACCTTGAC CTGGAACTCT GGATCCCTGT CCAGTGGTGT 3' 560

Lym-1 Light Chain Variable Region DNA Sequence

5. CT CAG GTC CTG GGG TTG CTG CTG CTG TGG CTT ACA GTA GGT GTC AGA TGT 50 Gln Val Leu Gly Leu Leu Leu Leu Trp Leu Thr Val Gly Val Arg Cys

GAC ATC CAG ATG ACT CAG TCT CCA GCC TCC CTA TCT GCA TCT GTG GGA GAA ACT GTC ACC 110 Asp Ile Gln Met Thr Gln Ser Pro Ala Ser Leu Ser Ala ser Val Gly Glu Thr Val Thr

ATC ATA TGT CGA GCA AGT GTG AAT ATT TAC AGT TAT TTA GCA TGG TAT CAG CAG AAA CAG 170 Ile Ile Cys Arg Ala Ser Val Asn Ile Tyr Ser Tyr Leu Ala Trp Tyr Gln Gln Lys Gin $\checkmark$

GGA AAA TCT CCT CAG CTC CTG GTC TAT AAT GCC AAA ATC TTA GCA GAA GGT GTG CCA TCA 230 Gly Lys Ser Pro Gln Leu Leu Val Tyr Asn Ala Lys Ile Leu Ala Glu gly Val pro Ser

AGG TTC AGT GGC AGT GGA TCA GGC ACA CAG TTT TCT CTG AAG ATC AAC AGC CTG CAG CCT 290 Arg Phe Ser Gly Ser Gly Ser Gly Thr Gln Phe Ser Leu Lys Ile Asn Ser Leu Gln Pro

GAA GAT TTT GGG AGT TAT TAC TGT CAA CAT CAT TAI GGT ACA ITC ACG TTC GGC TCG GGG 350 Glu Asp Phe Gly Ser Tyr Tyr Cys Gln His His Tyr Gly Thr Phe Thr Phe Gly Ser Gly

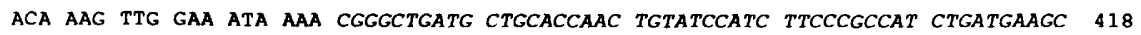
Thr Lys Leu Glu Ile Lys

TTGG $3^{\prime}$

FIGURE 4 Nucleotide sequences of Lym-1 $V_{H}$ and $V_{L}$ coding regions. Included are some of the signal sequences at $5^{\prime}$ ends and part of the constant regions at $3^{\prime}$ ends expressed in italics. The hypervariable loops are underlined. The arrows indicate errors detected in the previously published Lym-1 $V_{L}$ coding region. ${ }^{(18)}$ These sequences have been deposited with the EMBL gene bank under accession numbers X53483 and X53484, respectively.

primer $\kappa-17$; template amplified with $\mathrm{V}_{\mathrm{H}}$ primers HS-1 and PO3, respectively; template amplified with $\mathrm{V}_{\mathrm{H}}$ primer $\mathrm{G} 2 \mathrm{~A}$; template amplified with $\mathrm{V}_{\mathrm{H}}$ primer $\gamma-15$. As expected, in most cases the singlestranded DNA product ran slightly behind its double-stranded DNA template. ${ }^{(26)}$ Some samples displayed a smear of bands in the expected region of the gel.

Nucleotide sequencing of the $\mathrm{V}_{\mathrm{H}}$ and the $V_{L}$ coding regions of Lym- 1 was performed using the primers listed in Table
1. To check for sequence errors introduced by reverse transcriptase and Taq DNA polymerase, the sequences of the $\mathrm{V}_{\mathrm{H}}$ and $\mathrm{V}_{\mathrm{L}}$ coding regions were determined using two independent PCR products from different batches of cDNA for each. Separately, the $V_{H}$ and $V_{L}$ coding regions inserted into plasmids were sequenced. The sequences were identical. Figure 4 shows the nucleotide sequences of the Lym-1 $V_{H}$ and $V_{L}$ regions, with some of the signal peptide sequences at their 5' termini and part of the constant regions at their $3^{\prime}$ termini. We detected two errors in the previously published $^{(18)} V_{L}$ region: $A \rightarrow G$ (position 191) and $C \rightarrow A$ (position 330). The sequences of Lym-1 $V_{H}$ and $V_{L}$ have been submitted to the EMBL gene bank under accession numbers X53483 and X53484, respectively.

\section{PCR-fused Lym-1 SCA Gene}

Figure 5 shows the 954-bp PCR-fused Lym-1 SCA protein gene. After the firststep fusion, $10 \mu \mathrm{l}$ of amplified product was run in $1.5 \%$ agarose gel; a weak DNA band of the expected 1088-bp size was visible and is indicated by an arrow. However, the product of the heminested second-step amplification was a very sharp and strong DNA band of the expected 954-bp size. To confirm the sequence of the gene, the PCR product was introduced into the TA cloning vector, which was used to transform Escherichia coli INV $\alpha \mathrm{F}^{\prime}$. The cells were cultured, the plasmid was isolated, and the insert se-

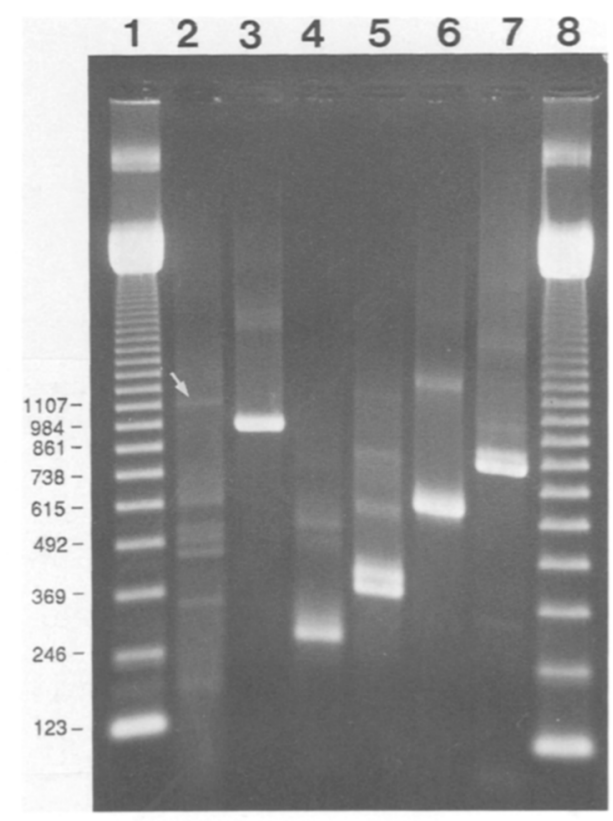

FIGURE 5 Gel electrophoretic analysis of the PCR-fused Lym-1 SCA protein gene. (Lanes 1,8) 123-bp DNA marker ladder (bp at left). (Lane 2) Products of the first-step PCR; the weak band of $1088 \mathrm{bp}$ is indicated by an arrow. (Lane 3) Products of the second-step PCR, which is a sharp DNA band of $954 \mathrm{bp}$. (Lanes 4-7) PCR-amplified DNA fragments using the fused gene in lane 3 as the template and these heminested primers: EOP and ompA-L (lane 4); EOP and 1A (lane 5); EOP and link-L (lane 6); EOP and 1G (lane 7). 


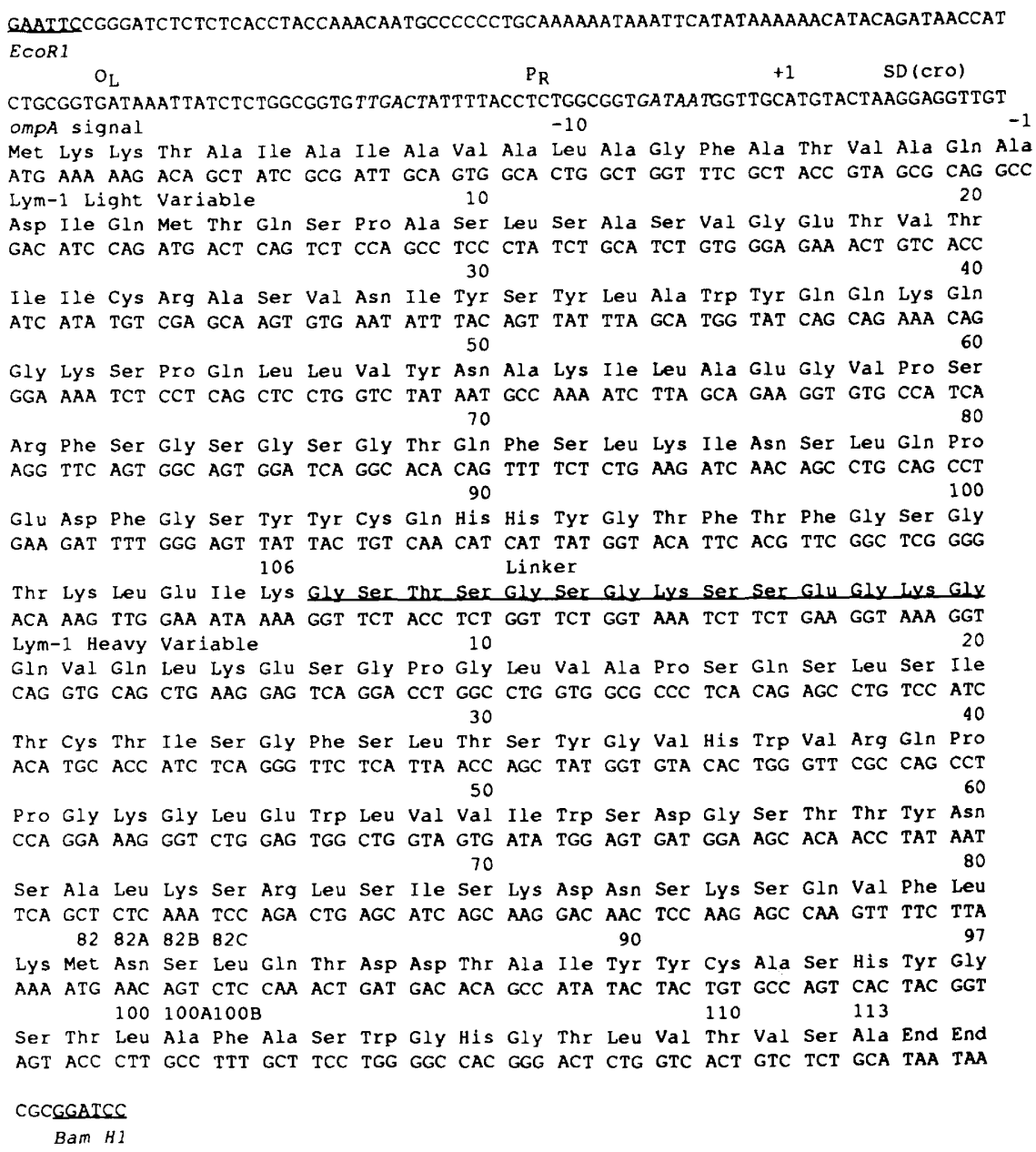

FIGURE 6 The PCR-generated Lym-1 SCA protein gene sequence. Included and labeled are the $o_{\mathrm{L}} / p_{\mathrm{R}}$ promoter, ompA signal sequence, Lym-1 $\mathrm{V}_{\mathrm{L}}$ and $\mathrm{V}_{\mathrm{H}}$, and a 14-amino-acid linker (underlined).

quenced using Sequenase 2.0 according to the supplier's protocol. The sequence of the gene is shown in Figure 6.

\section{DISCUSSION}

Here, we describe a strategy for amplifying the $\mathrm{V}_{\mathrm{H}}$ and $\mathrm{V}_{\mathrm{L}}$ genes of Lym-1. The variable regions of antibody genes convey antibody specificity; thus, it is critical to accurately reproduce the variable regions of both the heavy and light chains in preparation for engineered antibodies. In agreement with other researchers, ${ }^{(12,27)}$ we have demonstrated the success of using consensus primers in the amplification of antibody variable region genes. The genes were sequenced by three independent protocols and no discrepancies were detected.

The PCR technique has been used to construct and/or amplify genes by several approaches. ${ }^{(13-16,28)}$ In this paper we extend the strategy to construct a 954-bp Lym-1 SCA protein gene using nine synthetic oligonucleotides and two PCR-produced $\mathrm{V}_{\mathrm{H}}$ and $\mathrm{V}_{\mathrm{L}}$ coding regions by a two-step PCR method. We demonstrate that the strategy greatly simplifies the time-consuming process of preparing a recombinant gene.

Taq DNA polymerase lacks 3'-exonucleolytic proofreading activity. In agreement with other researchers, ${ }^{(29,30)}$ we found that the fused products produced by the Taq enzyme contained errors, including base substitutions, deletions, and insertions (data not shown). The fused gene prepared by Vent $_{\mathrm{R}}$ DNA polymerase, which has the $3^{\prime} \rightarrow 5^{\prime}$ exonuclease proofreading activity, was introduced into the vector by restriction cloning, and the correct nucleotide sequence was produced.

The advantages of this strategy include its simplicity, speed, efficiency, and low cost. Construction of a gene by PCR fusion eliminates the need for incorporation of internal restriction sites to assemble the gene. Except for insertion into the cloning vector, neither restriction enzymes nor ligase are needed. The two-step PCR recombination can be performed in a single day. DNA can be prepared in microgram quantities. No purification is required, and the product can be directly introduced into the TA cloning vector. Although we constructed a PCR fusion gene of $954 \mathrm{bp}$, it seems that longer DNA fragments can be generated by the same strategy. In addition, the technique can be applied to genes other than antibodies.

\section{ACKNOWLEDGMENTS}

We thank Linda Kroger, M.S., for technical advice and assistance and manuscript review. This research was supported in part by grants from the Department of Energy (DE-FG03-84ER-60233) and the National Cancer Institute (CA47829). P.H.G. was supported in part by the Dugally Research Fund. F.J.M. is an American Cancer Society Career Development Award recipient.

\section{REFERENCES}

1. DeNardo, S.J., G.L. DeNardo, L.F. O'Grady, D.J. Macey, S.L. Mills, A.L. Epstein, J. Peng, and J.P. McGahan. 1987. Treatment of a patient with B cell lymphoma by I-131 Lym-1 monoclonal antibodies. Int. J. Biol. Markers 2: 49-53.

2. DeNardo, S.J., G.L. DeNardo, L.F. O'Grady, E. Hu, V.M. Sytsma, S.L. Mills, N.B. Levy, D.J. Macey, C.H. Miller, and A.L. Epstein. 1988. Treatment of B cell malignancies with 131-I Lym-1 monoclonal antibodies. Int. J. Cancer (Suppl.) 3: 96-101.

3. DeNardo, G.L., S.J. DeNardo, L.F. O'Grady, N.B. Levy, G.P. Adams, and S.L. Mills. 1990. Fractionated radioimmunotherapy of B-Cell malignancies with 131I-Lym-1. Cancer Res. 50: 1014s-1016s.

4. Adams, G.P., S.J. DeNardo, S.V. Deshpande, G.L. DeNardo, C.F. Meares, M.J. McCall, and A.L. Epstein. 1989. Effect of mass of In-111-benzyl-EDTA monoclonal antibody on hepatic uptake and processing in mice. Cancer Res. 49: 1707-1711.

5. Sancho, J., E. Gonzales, J.F. Escandero, and J. Egido. 1984. Binding kinetics of monomeric and aggregated IgG to Kupffer cells and hepatocytes of mice. Immunology 53: 283-289.

6. Colcher, D., R. Bird, M. Roselli, K.D. Hard- 
man, S. Johnson, S. Pope, S.W. Dodd, M.W. Pantoliano, D.E. Milenic, and J. Schlom. 1990. In vivo tumor targeting of a recombinant single-chain antigen-binding protein. J. Natl. Cancer Inst. 82: 11911197.

7. Milenic, D.E., T. Yokota, D.R. Filpula, M.A.J. Finkelman, S.W. Dodd, J.F. Wood, M. Whitlow, P. Snoy, and J. Schlom. 1991. Construction, binding properties, metabolism, and tumor targeting of a single-chain $\mathrm{Fv}$ derived from the pancarcinoma monoclonal antibody CC49. Cancer Res. 51: 6363-6371.

8. Bird, R.E., K.D. Hardman, J.W. Jacobson, S. Johnson, B.M. Kaufman, S. Lee, T. Lee, S.H. Pope, G.S. Riordan, and M. Whitlow. 1988. Single-chain antigen-binding proteins. Science 242: 423-426.

9. Cheadle, C., L.E. Hook, D. Givol, and G.A. Ricca. 1992. Cloning and expression of the variable regions of mouse myeloma protein MOPC315 in E. coli: Recovery of active Fv fragments. Mol. Immunol. 29: $21-30$.

10. Garrard, L.J., M. Yang, M.P. O'Connell, R.F. Kelley, and D.J. Henner. 1991. Fab assembly and enrichment in a monovalent phage display system. Biotechnology 9: 1373-1377.

11. Kohl, J., F. Ruker, G. Himmler, E. Razazzi, and $\mathrm{H}$. Katinger. 1991. Cloning and expression of an HIV-1 specific single-chain Fv region fused to E. coli alkaline phosphatase. Ann. N.Y. Acad. Sci. 646: 106114.

12. Orlandi, R., D.H. Gussow, P.T. Jones, and G. Winter. 1989. Cloning immunoglobulin variable domains for expression by the polymerase chain reaction. Proc. Natl. Acad. Sci. 86: 3833-3837.

13. Horton, R.M., H.D. Hunt, S.N. Ho, J.K, Pullen, and L.R. Pease. 1989. Engineering hybrid genes without the use of restriction enzymes: Gene splicing by overlap extension. Gene 77: 61-68.

14. Mullinax, R.L., E.A. Gross, B.N. Hay, J.R. Amberg, M.M. Kubitz, and J.A. Sorge. 1992. Expression of a heterodimeric Fab antibody protein in one cloning step. BioTechniques 12: 864-869.

15. Jayaraman, K., J. Shah, and J. Fyles. 1989. PCR mediated gene synthesis. Nucleic Acids Res. 17: 4403.

16. Dillon, P.J. and C.A. Rosen. 1990. A rapid method for the construction of synthetic genes using the polymerase chain reaction. BioTechniques 9: 298-300.

17. Larrick, J.W., L. Danielsson, C.A. Brenner, M. Abrahamson, K.E. Fry, and C.A.K. Borrebaeck. 1989. Rapid cloning of rearranged immunoglobulin genes from human hybridoma cells using mixed primers and the polymerase chain reaction. Biochem. Biophys. Res. Commun. 160: $1250-1256$.

18. Wellman, A.A. and C.F. Meares. 1990. Se- quences of the Lym-1 antibody heavy and light chain variable regions. Nucleic Acids Res. 18: 5281 .

19. Madewell, B.R., P.H. Gumerlock, K.A. Saunders, F.J. Meyers, S.A. Kraegel, and E.S. Kawasaki. 1989. Canine and bovine ras family expression detected and discriminated by use of polymerase chain reaction. Anticancer Res. 9: 1743-1750.

20. Chirgwin, J.M., A.E. Przybyla, R.J. MacDonald, and W.J. Rutter. 1979. Isolation of biologically active ribonucleic acid from sources enriched in ribonuclease. Biochemistry 18: 5294-5299.

21. Sambrook, J., E.F. Fritsch, and T. Maniatis. 1989. Extraction, purification, and analysis of mRNA from eukaryotic cells. In Molecular cloning: A laboratory manual, 2nd ed., pp. 7.2-7.83. Cold Spring Harbor Laboratory Press, Cold Spring Harbor, New York.

22. Southern, E.M. 1975. Detection of specific sequences among DNA fragments separated by gel electrophoresis. J. Mol. Biol. 98: 503-517.

23. Gumerlock, P.H., Y.J. Tang, F.J. Meyers, and J. Silva Jr. 1991. Use of the polymerase chain reaction for the specific and direct detection of Clostridium difficile in human feces. Rev. Infect. Diseases 13: $1053-1060$.

24. Saunders, K.A., B.R. Madewell, V.I.C. Oreffo, S.A. Kraegel, and P.H. Gumerlock. 1992. Nucleotide sequence of canine $\mathrm{C}-\mathrm{N}$ ras: Codons 1 to 71 . Am. J. Vet. Res. 53: $600-603$.

25. Sanger, F., S. Nicklen, and A.R. Coulson. 1977. DNA sequencing with chain-terminating inhibitors. Proc. Natl. Acad. Sci. 74: 5463-5467.

26. Wong, D.M., P.H. Weinstock, and J.G. Wetmur. 1991. Branch capture reaction: Displacers derived from asymmetric PCR. Nucleic Acids Res. 19: 2251-2259.

27. Chaudhary, V.K., J.K. Batra, M.G. Gallo, M.C. Willingham, D.J. FitzGerald, and I. Pastan. 1990. A rapid method of cloning functional variable-region antibody genes in Escherichia coli as single-chain immunotoxins. Proc. Natl. Acad. Sci. 87: 1066-1070.

28. Daugherty, B.L., J.A. DeMartino, M. Law, D.W. Kawka, I.I. Singer, and G.E. Mark. 1991. Polymerase chain reaction facilitates the cloning, CDR-grafting and rapid expression of a murine monoclonal antibody directed against the CD18 component of leukocyte integrins. Nucleic Acids Res. 19: 2471-2476.

29. Foguet, M. and H. Lubbert. 1992. Precise and efficient construction of synthetic genes. BioTechniques 13: 674-675.

30. Gyllensten, U.B. 1989. PCR and DNA sequencing. BioTechniques 7: 700-708.

Received April 2, 1993; accepted in revised form June 25, 1993. 


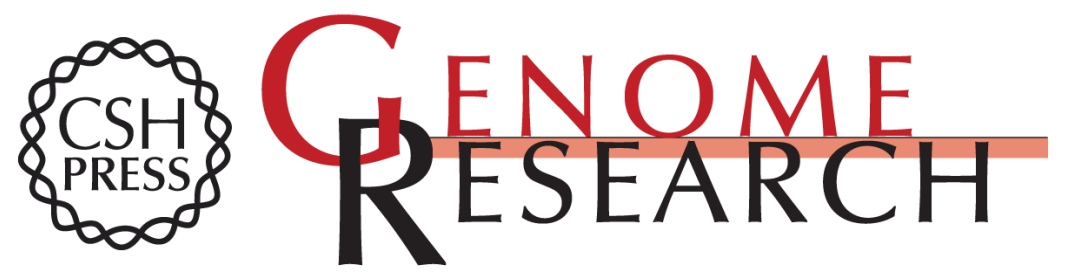

\section{Rapid PCR construction of a gene containing Lym-1 antibody variable regions.}

X B Shi, P H Gumerlock, A A Wellman, et al.

Genome Res. 1993 3: 46-53

References This article cites 29 articles, 7 of which can be accessed free at: http://genome.cshlp.org/content/3/1/46.full.html\#ref-list-1

License

Email Alerting

Receive free email alerts when new articles cite this article - sign up in the box at the Service top right corner of the article or click here.

\section{Affordable, Accurate Sequencing.}

To subscribe to Genome Research go to: https://genome.cshlp.org/subscriptions 